\title{
Role and Importance of Vitamin D in Asthma and Other Allergic Diaseases
}

\author{
Öner Özdemir ${ }^{1}$ (D), Çağla Karavaizoğlu² (1) \\ 1Division of Pediatric Allergy and Immunology, Department of Pediatrics, Sakarya University School of Medicine Training and Research Hospital, \\ Sakarya, Turkey \\ ${ }^{2}$ Department of Pediatrics, Sakarya University School of Medicine Training and Research Hospital, Sakarya, Turkey
}

Cite this article as: Özdemir Ö, Karavaizoğlu Ç. Role and Importance of Vitamin D in Asthma and Other Allergic Diaseases. JAREM 2018; 8: 1-8.

\begin{abstract}
Vitamin $D$ is a steroid hormone that has important effects on bone metabolism and neuromuscular functions. Recent research has indicated that it also has a role in the development and treatment of allergic diseases by affecting the immune system through different mechanisms. After vitamin $D$ is activated by liver and kidney in the body, it shows its effect by attaching to its receptor on the cell membrane. The vitamin $D$ receptor is expressed on all tissue cells, particularly on those of the respiratory and intestinal epithelium by which extra-skeletal functions of vitamin D such as anti-inflammatory effects and immunomodulation are mediated. As a consequence, it is assumed that vitamin D and its receptor have effects on various systems in the human body. Some researchers suggest that deficiency or excess of vitamin $D$ in the diet causes an increase in asthma and allergic diseases. Therefore, vitamin D supplementation is currently advised by some authors for the prevention and treatment of allergic diseases. It has commonly been reported that vitamin $D$ is particularly found to be useful in preventing asthma attack and in managing resistant asthma. Currently, there has been an increase in the literature regarding the role of vitamin $D$ in the treatment of atopic dermatitis and chronic urticaria-angioedema.
\end{abstract}

Keywords: Vitamin D, asthma, allergy, vitamin D receptor, eczema, urticaria

ORCID IDs of the authors: Ö.Ö. 0000-0002-5338-9561; Ç.K. 0000-0001-6294-9682

\section{INTRODUCTION}

Asthma is an airway or chronic inflammatory obstructive disease in which genetic and environmental factors play a role, which is usually common in the lungs but variable and often reversible spontaneously or with treatment (1). In developed countries, there is a reported marked increase in the frequency of asthma and allergic diseases over the past past 2-3 decades. (2).

This increase is thought to be due to changing living conditions, such as changes in diet with vitamin $D$, trace elements, inadequate consumption of antioxidants, and varying rates of lipids, and environmental differences, such as hygiene and microflora change. The most common hypotheses in this regard are "diet," "hygiene," and "microflora" $(3,4)$.

The hygiene hypothesis, which tries to explain the incidence of allergic diseases, suggests that frequent infections in early childhood may convert the child's immune system into a non-allergic Thelper 1 (Th1) pathway and reduce the risk of asthma and other allergic diseases (1). The microflora hypothesis that began to be more popular along with this hypothesis can help explain how the crowd in family (big family), birth order, and attending a day care center can reduce the risk of asthma and allergic disease (5-7). Recent increases in the predisposition toward the use of probiotics in the third trimester in a pregnant mother, in a baby after birth, and in various allergic diseases demonstrate the importance of hygiene and microflora hypotheses (3). Dietary vitamin D leads to allergic disease when it is in excess according to some, and when it is insufficient according to other studies (Figure 1).

In this review, we will discuss the positive effects of vitamin D on allergic diseases with various mechanisms, as in many diseases, in light of recent literature.

\section{METABOLISM OF VITAMIN D}

Vitamin $D$ is a pro-hormone that is in steroidal structure and is required for the regulation of calcium $(\mathrm{Ca})$ and phosphorus levels in blood, which are known to play important roles in bone metabolism and neuromuscular functions, and for the proper maintenance of bone regeneration cycle (8).

Vitamin D has two forms in humans. These are vitamin D2 (ergocalciferol, 25(OH)D2) and vitamin D3 (cholecalciferol, 25(OH) D3). Vitamin D3 is synthesized from 7-dehydrocholesterol in the skin with sunlight. 7-Dehydrocholesterol is first converted into pre-vitamin D3 with ultraviolet B sunlight by wavelengths ranging from 290 to 315 . Then, vitamin D3 is derived from pre-vitamin D3 through isomerization. Vitamin D2 is formed as a result of the contact of plants with sunlight. Vitamin D3, which is formed by sunlight, fulfills $90 \%-95 \%$ of the amount that is needed by the human body. Vitamins D2 and D3, which are derived from foods 
and synthesized in the skin, are converted to 25-hydroxyvitamin D2 $(25(\mathrm{OH}) \mathrm{D} 2)$ and 25-hydroxyvitamin D3 $(25(\mathrm{OH}) \mathrm{D} 3)$ in the liver. As $25(\mathrm{OH})$ D is synthesized in the liver, it is transported to the kidney tissue by binding to the vitamin D-binding protein (DBP). The $25(\mathrm{OH}) \mathrm{D}$ vitamin released from the DBP-25(OH)D vitamin complex entering the renal tubules return to $1,25(\mathrm{OH})_{2} \mathrm{D}$, which is the active form of vitamin $D$ and 1- $\alpha$-hydroxylase enzyme in the mitochondrial cytochrome P450 enzyme system (9).

Calcitriol $(25(\mathrm{OH}) \mathrm{D})$ is used to describe both $25(\mathrm{OH}) \mathrm{D} 3$ and 25(OH)D2 levels. Blood 25(OH)D level is the best indication of tissue vitamin status. For this reason, it is the basic parameter used to evaluate vitamin $D$ deficiencies. The major form of vitamin $D$ in the circulation is $25(\mathrm{OH}) \mathrm{D} 3$ with a half-life of approximately 2-3 weeks. Plasma $1,25(\mathrm{OH})_{2} \mathrm{D}$ level may be normal or even higher in cases of deficiency; therefore, it is not used to evaluate the status of vitamin D (10-13). For serum $25(\mathrm{OH})$ D3 level, normal values are accepted as $30-100 \mathrm{ng} / \mathrm{mL}(75-250$ $\mathrm{nmol} / \mathrm{l})$, insufficiency is $21-29 \mathrm{ng} / \mathrm{mL}(51-74 \mathrm{nmol} / \mathrm{l})$, and deficiency is $<20 \mathrm{ng} / \mathrm{mL}(<50 \mathrm{nmol} / \mathrm{l})$ (3). Although these are the values required for vitamin $\mathrm{D}$ to be effective in calcemia/bone, these are the same levels sufficient to be effective on other systems, including extracalcemic (non-bone) tissues or immune system (Table 1), or are higher levels required? Further studies are needed in this regard (10-13).

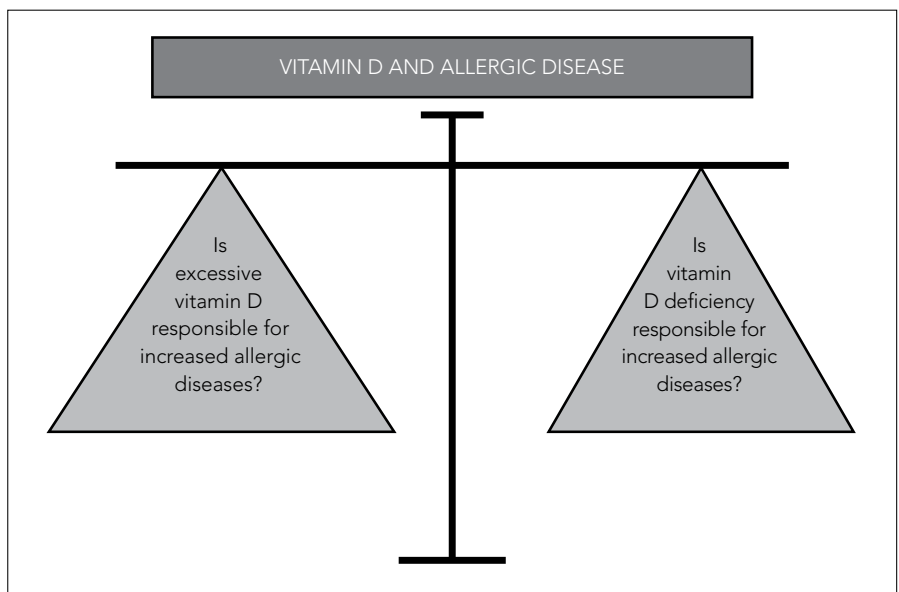

Figure 1. Two hypotheses showing the effect of vitamin D on allergic diseases are presented
The active $1,25(\mathrm{OH})_{2} \mathrm{D}$ gains functionality with two pathways within the cell. These are the "genomic" and "non-genomic" pathways. The $1,25(\mathrm{OH})_{2} \mathrm{D}$ that is transported to the tissues via DBPs in the genomic (through genes) pathway enters the cell and complexes with the vitamin D receptor (VDR). This complex binds to specific DNA regions as a ternary complex by taking the retinoic acid $\mathrm{X}$-receptor together. While the resulting ternary complex causes some genes (osteocalcin, Ca-binding protein, and 24-hydroxylase) to be transcribed, it decreases the transcription of some genes (inflammatory genes, interleukin (IL)-2, and IL-12). In the non-genomic pathway, vitamin D activates secondary signaling pathways in the cytoplasm by binding to VDRs on the plasma membrane. This receptor is expressed in all tissues and is responsible for the extracellular function of vitamin $D$. As a result of this pathway, the Ca channels in the cell membrane are activated. The non-genomic pathway is rather active in the pancreas $\beta$ cells, smooth muscles, heart muscles, intestinal cells, and monocytes. It has been suggested that this pathway is associated with the development of psoriasis, type I diabetes, rheumatoid arthritis, multiple sclerosis, Crohn's disease, hypertension, cardiovascular disease, and some common cancers $(9,14)$.

\section{FUNCTIONS OF VITAMIN D IN THE BODY}

Vitamin D increases Ca absorption in the kidneys, bones, and intestines. It takes effect in the distal tubule cells together with the parathyroid hormone (PTH). A total of $1 \%$ of $\mathrm{Ca}$ filtered from the distal tubules is absorbed. It acts on bone tissue and increases Ca mobilization. It acts together with PTH for this. Vitamin D that binds to the VDR in the intestinal epithelial cells increases the synthesis of Ca-binding protein, thereby increasing the active transport of $\mathrm{Ca}$. In addition, in studies conducted on vitamin D in recent years, it has been known that it has an effect on many systems other than bone metabolism (8-14). The VDRs, which are expressed in all tissues, especially in the respiratory and intestinal epithelium, and which are responsible for the functions of nonskeletal vitamin D (anti-inflammatory and antiproliferative), are also receptors that are found in T or B lymphocytes and mononuclear cells and are responsible for immunomodulation (Figure 2).

\section{VITAMIN D AND ITS IMPACT ON THE IMMUNE SYSTEM}

The effect of vitamin D on natural immunity manifests itself with supporting antimicrobial functions and with suppressing inflammatory activity. The treatment of human monocytes with calcitriol

Table 1. Vitamin D levels and their meanings for human health

\begin{tabular}{|c|c|c|c|}
\hline Vitamin D state & $\mathrm{Ng} / \mathrm{mL}$ & $\mathrm{Nmol} / \mathrm{L}$ & Its importance for health \\
\hline Deficiency & $<20$ & $<50$ & Associated with rachitism in infants and children and osteomalacia in adults \\
\hline Insufficiency & $21-29$ & $52.5-72.5$ & $\begin{array}{l}\text { Generally accepted to be insufficient for bones and general health condition } \\
\text { in healthy individuals }\end{array}$ \\
\hline Sufficiency & $\geq 30$ & $>75$ & $\begin{array}{l}\text { Generally accepted to be sufficient for bones and general health condition in } \\
\text { healthy individuals }\end{array}$ \\
\hline Extra-calcemic effect & $\geq 30$ (?) & $>75$ (?) & Immunomodulation \\
\hline Toxicity & $>100$ & $>250$ & Potential emergent side effects at high levels \\
\hline
\end{tabular}




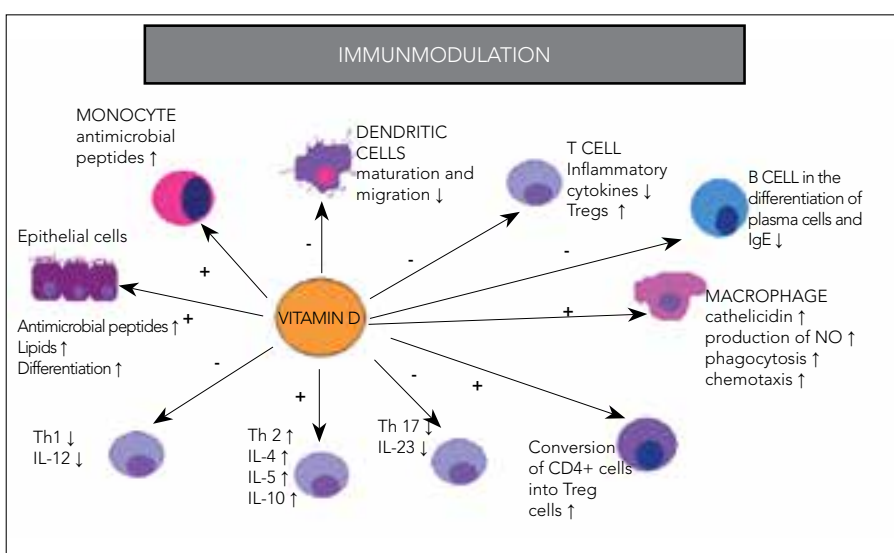

Figure 2. The effects of vitamin D causing modulation in innate and acquired immune system cells are shown

inhibits the expression of Toll-like receptor (TLR)-2 and TLR-4 from TLRs. TLR is important for the early onset of inflammatory immune response. Decreasing TLR expression in monocytes with calcitriol reduces the production of tumor necrosis factor- $\alpha$, which is among the proinflammatory cytokines. In addition to the inhibition of the inflammatory functions of innate immune cells, vitamin $D$ also decreases the acquired effective immune response and stimulates the synthesis of antimicrobial peptide (AMP), primarily cathelicidin. This explains the relationship between vitamin $D$ deficiency and infections $(15,16)$.

In dendritic cells, the surface expression of antigen-presenting molecules (CD1a, major histocompatibility complex class II, and costimulatory molecules CD40, CD80, and CD86) diminishes in the presence of calcitriol and does not fully mature. Proinflammatory cytokine IL-12 production decreases, and anti-inflammatory cytokine IL-10 production increases (Figure 2). This effect is realized with the increase in the CD4+ Treg cell population that directly acts on CD4+ T cells and secretes IL-10 (17).

After $1,25(\mathrm{OH})_{2} \mathrm{D}$ reaches the nuclear receptor and is activated, there is a decrease in the conversion of monocytes to macrophages, resulting in decreased antigen presentation of macrophages to $T$ lymphocytes. In addition, both immunoglobulin synthesis from B lymphocytes and maturation of antigen-presenting dendritic cells are suppressed (Figure 2). Thus, sensitivity reactions that are delayed due to $B$ cells are inhibited by $1,25(\mathrm{OH})_{2} \mathrm{D}$. In addition to antiproliferative activity, it also inhibits the formation and functions of natural killer lymphocytes via the lymphocytes activated as a result of the activation of the VDR (18).

\section{VDR POLYMORPHISM}

VDR, which is a member of the nuclear receptor family and is expressed in all tissues, is responsible for extracellular vitamin D functions. The effect of VDR has been demonstrated on 291 genes and 80 different metabolic pathways. $1,25(\mathrm{OH})_{2} \mathrm{D} 3$ upregulates $2 / 3$ of these genes (the expression increases) and downregulates $1 / 3$ of them (the expression decreases) through VDR. Some of the non-bone effects on the respiratory and intestinal epithelial barrier are antioxidant, anti-inflammatory, antiproliferative, and immunomodulation effects (15-18).
Recently, the role of VDR polymorphisms in the development of asthma has begun to be revealed. For example, in addition to the fact that VDR knockout mice have been shown to be resistant to asthma, it has been shown that the induction of bronchial hyperreactivity and inflammation is inhibited in patients with hereditary vitamin D-resistant rickets that develops as a result of the mutated VDR (19). As a result, it has been shown that the development of asthma can be prevented as a result of VDR elimination or mutation. In addition, it has been shown that the control and recovery of the disease and daily activities can be easily provided in patients with asthma with Apal a allele of the VDR rather than Taql, Bsml, and Fokl C alleles (20). It has been reported that this VDR polymorphism establishes a ground for the development of asthma in people with Taql, Bsml, and Fokl $C$ alleles (21). This literature suggests that not only vitamin D but also its receptor (VDR) may be important in the development of asthma and allergic diseases.

\section{CAUSES AND CONSEQUENCES OF VITAMIN D DEFICIENCY}

The most frequent cause of vitamin $D$ deficiency is the inability to get enough exposure to sunlight, wearing closed clothes, and lack of dietary intake (especially seafood). Vitamin D deficiency can also be seen in some cases, such as geographical location, sunscreen, depth of skin color, some medications (anticonvulsant, rifampin, glucocorticoids, and antiretroviral, among others), hepatic-renal insufficiencies, nephrotic syndrome, and diseases leading to obesity and malabsorption (Crohn's, celiac, and Whipple's diseases and cystic fibrosis, among others) (8-12).

The most common diseases that occur after the deficiency are rickets and bone diseases, such as osteomalacia and osteoporosis. In addition, it has been found to be associated with schizophrenia, depression, a tendency for infections, lung and cardiovascular diseases, and even with cancer tendency. Vitamin $D$ also has an effect on autoimmune diseases (8-14). Its effects on allergic diseases, such as asthma, in the immune system will be explained further in this review.

\section{VITAMIN D AND ITS RELATIONSHIP WITH ASTHMA BRONCHITIS}

The effect of vitamin D on asthma development and treatment is summarized in Table 2 and will be further discussed here. There are several hypotheses regarding the effect of vitamin D on allergy development. First, the increase in allergic diseases is thought to occur because the excessive use of vitamin D makes the Th2 response dominant. Vitamin $D$ supplementation in the maternal period (pregnancy) and early childhood was considered to be responsible for this (Figure 1). Second, the increase seen in allergic diseases, such as asthma, is related to the widespread lack of vitamin $D$, and there are studies suggesting that this is caused by vitamin D deficiency, which affects Treg cells (22-25).

\section{Vitamin D Level in Pregnancy or Birth and Allergic Disease Development (Birth Cohorts)}

In many large birth cohort studies, the relationship between vitamin D supplementation during infancy and the development of asthma and allergy in the later period was investigated (26). The results of these studies that evaluated the vitamin $D$ level of the 
mother during pregnancy and the risk of allergy development are conflicting and insufficient.

Studies have been conducted to prove that high level of maternal plasma vitamin $\mathrm{D}(25(\mathrm{OH}) \mathrm{D} 3)$ in late pregnancy is associated with an increased risk of eczema (atopic dermatitis) in 9-month-old infants (27). However, in some other studies, recurrent wheezing was found to be less frequent in children of mothers, receiving higher amount of vitamin $D$ during their pregnancy, when they reached 3 years old $(28,29)$. It has been shown in some studies through 25(OH)D levels in the cord serum that there is an inverse relationship between multitrigger wheezing at 2 years and the risk of wheezing development at 5 years $(30,31)$. However, it was found that the rate of wheezing is lower at 5 years old as a result of maternal vitamin D supplementation (32), but in another study, the use of $400 \mathrm{IU} /$ day maternal vitamin D versus $2800 \mathrm{IU} /$ day does not cause a significant decrease in this disease at 3 years (33). It was shown in the study conducted by von Mutius et al. (34) that prenatal vitamin $D$ does not prevent the development of asthma in children. The Vitamin D Antenatal Asthma Reduction Trial study, which was a study to reduce asthma using vitamin $D$ in the antenatal period, compared the effect of $4400 \mathrm{IU} /$ day versus 400 IU/day vitamin D given to 806 risky pregnant mothers at the end of 3 years, and the incidence of asthma decreased by $6.1 \%$ in children born, but it was not found to be significant (35).

These results indicate that vitamin $\mathrm{D}$ may be important in the development of allergic disease when given in pregnancy or in early childhood. It is thought, however, that varying doses of vitamin $D$ may alter the effect of the pathogenesis of allergic disease and asthma.

\section{Asthma Prevalence and its Relationship with Serum Vitamin D Levels}

In the study conducted in adults aged 21-50 years by ConfinoCohen et al. (36), 4-year hospital records were examined, and vitamin D measurements were made in 307,900 or $1,783,334$ patients, and 21,737 (6.9\%) of these were found to have doctordiagnosed asthma. There was no relationship between doctor-diagnosed asthma prevalence and vitamin D levels. In a systematic compilation of cohort studies conducted by Rajabbik et al. (37), the relationship between low vitamin $\mathrm{D}$ levels and the diagnosis of asthma in children has not been clearly demonstrated.

\section{Relationship of Vitamin D with Asthma and Respiratory Tract Infections}

Vitamin $\mathrm{D}$ has been found to be effective on the predisposition and responsiveness to the infections triggering wheezing at early ages (38). It is thought that vitamin $D$ reduces respiratory tract infections (respiratory syncytial virus and rhinovirus, among others) and consequently contributes to the prevention and control of asthma. It is also thought that vitamin D can prevent asthma attacks with different mechanisms. It accomplishes this with immunomodulating, as well as antimicrobial, effects by increasing the synthesis of AMP proteins, such as $\beta$-defensin and cathelicidin, and by reducing nuclear factor kappa $\beta$-related chemokine (CXCL10) and interferon- $\beta$ secretion induced by the virus in the respiratory epithelium (39).

In the National Health and Nutrition Examination Survey III trial, patients with low 25(OH)D3 levels were found to have a higher upper respiratory tract infection rate, which is independent of the season and more prominent in patients with asthma (40). In some studies, it has also been shown that the use of vitamin $D$ is beneficial during asthma attacks (41). In another study, >300 Japanese school children were examined, and a 4-month use of 1200 IU/ day vitamin $D$ showed that $42 \%$ of the children had less influenza $A$ infection, and patients with asthma had six times fewer attacks (42). Childhood Asthma Management Program, a cohort study, was performed in 1024 children, and fewer severe symptoms and sequelae due to viral infections were observed (43). In a meta-analysis of five studies, it has been concluded that vitamin D supplementation (500 IU/day) in children may be beneficial in preventing attacks and controlling asthma (44). However, as there are also studies showing the opposite, there is still not enough data and consensus on this issue (45).

\section{Effect of Vitamin D on Lung Functions}

There are clinical observational studies showing that low vitamin D $(25(\mathrm{OH}) \mathrm{D} 3)$ levels are associated with impaired lung capacity ( $\downarrow$ forced expiratory volume in one second/forced vital capacity) and increased bronchial responsiveness. In addition, low vitamin D levels increase the risk of asthma exacerbation and steroid need and lead to steroid non-responsiveness, poor asthma control, and increased hospitalization (41-45). Higher vitamin D levels have also been found to be associated with better lung functions. In a cross-sectional study, the analysis of 25,000 adults showed a strong association between low serum 25(OH)D3 levels and decreased lung function (46). In another study, it was shown that low vitamin $D$ levels at birth are associated with high airway resistance in childhood (47).

\section{Treatment-Resistant and Steroid-Resistant Asthma}

Vitamin D is thought to play an important role in asthma and allergic diseases due to its immunomodulatory properties (Figure 2) (48). In addition, the severity and poor control of the disease have been found to be associated with vitamin $D$ levels in patients with vitamin $\mathrm{D}$ deficiency and inadequacy. There are also studies proving that steroid need is associated with disease severity or exacerbation and vitamin D levels (49). It is known that vitamin D has a modulatory effect on the smooth muscle of the respiratory tract and an effect reducing eosinophilic inflammation (50). It has also been shown that active vitamin $D$ suppresses elevated levels of IL-17A in resistant asthma and reverses impaired induction of T regulatory cells (51). In addition to these data, it has been noted in other studies that patients with more severe asthma may have lower levels of vitamin $D$ because of fewer outdoor activities and less sun exposure (23).

\section{Studies Performed in Patients with Asthma and Reported from Turkey}

In addition to the studies performed in steroid-resistant patients in our country, the relationship between childhood asthma and vitamin D deficiency was questioned in the study by Uysalol et al. (52), and an inverse relationship was observed between vitamin $\mathrm{D}$ deficiency and asthma. There are also studies reporting that asthma is associated with a high level of vitamin D deficiency and insufficiency, that the disease is more severe, and that there is an association between poorly controlled asthma and vitamin $D$ levels (49). 


\section{Vitamin D and its Effects on Allergen Immunotherapy}

It has been shown that the use of vitamin D during allergen immunotherapy increases the long-term effect of specific immunotherapy in allergic mouse models (53). Clinical and immunologic efficacy of immunotherapy in young patients with asthma was found to be correlated with 25(OH)D serum concentration. In a previous study, it was found that the effect of immunotherapy on reducing asthma symptoms and its effect freeing from the corticosteroids are more significant in those who had a high vitamin $D$ level and underwent subcutaneous immunotherapy due to mite allergy (54). Combined use of vitamin D was shown to be more effective in reducing nasal and asthma symptoms in those who had allergic rhinitis and received sublingual immunotherapy specific to five different weed pollens (55).

\section{VITAMIN D AND ITS RELATIONSHIP WITH OTHER ALLERGIC DISEASES}

Vitamin D and its effect on the other allergic diseases are summarized in Table 2. It will be further detailed in light of recent literature as follows.

\section{Vitamin $D$ and its Effect on Allergic Rhinoconjunctivitis}

Serum vitamin $D$ levels in 49 patients with seasonal allergic conjunctivitis were found to be significantly lower than those in the control group in a study conducted in Konya, Turkey (56). In a study published in Norway in 2014, whereas low serum vitamin D levels in 1351 adult patients were found to be associated with increased risk of allergic rhinitis in men, they were associated with a reduced risk of allergic rhinitis in women. However, it has also been considered that this may be because female gender hormones can influence the immune response in the direction of Th1 (57). Although controversial results were obtained in studies reported in Korea, the serum levels of vitamin $D$ were shown to be higher in patients with vasomotor rhinitis in the control group, and they were higher in those with allergic rhinitis (58). Similarly, in the studies reported from Turkey, low serum vitamin $D$ levels were detected in patients with allergic and non-allergic rhinitis in comparison with the control group $(59,60)$. On the contrary, serum vitamin D levels were found to be higher in those with allergic rhinoconjunctivitis than in those in the control group (61).

\section{Vitamin D and its Relationship with Atopic Dermatitis}

In some studies, it was suggested that there is a negative relationship between vitamin $D$ levels and the prevalence and/or severity of atopic dermatitis, and vitamin $D$ deficiency was observed to be more prominent in patients with allergic sensitization and/or with severe disease (62). Observationally, it is known that the disease is common in the period when the sun is less. The use of heliotherapy (narrowband ultraviolet B) has also been demonstrated in anecdotal studies. Vitamin $D$ is thought to be involved in the formation of the stratum corneum barrier and in the synthesis of proteins such as filaggrin, via the regulation of keratinocyte proliferation and differentiation. It is also thought to reduce microorganism colonization $(63,64)$. Consistent with this information, in many clinical trials, a reduction in high SCORing Atopic Dermatitis (SCORAD) score and clinical improvement was reported in patients with eczema as a result of the use of vitamin $D(65)$. However, recent studies have also shown that vitamin D supplementation does not have an effect on eczema severity (66).

\section{Vitamin D and its Effect on Food Allergy}

Geographical location (exposure to sunlight) was found to have a directly proportional correlation with food allergy, and anaphylactic development was found to have a directly proportional correlation with adrenaline auto-injector usage. Similar findings have led to the development of the hypothesis of vitamin D-anaphylaxis (67). In countries such as Australia, the use of adrenaline auto-injector was found to be inversely correlated with melanoma development. Indirect exposure to sunshine has been shown to reduce the development of food allergy (68).

There are studies that indicate that vitamin $D$ deficiency may cause food allergy allergy by causing impaired immunity balance, increased Th2 lymphocyte ratio, and decreased number of T regulatory and tolerogenic dendritic cells, in addition to abnormal bowel barrier permeability (69).

Vitamin D and its Effect on Chronic Urticaria and Angioedema Thorp et al. (70) showed that adult patients with chronic urticaria were found to have lower levels of vitamin $D$ than the control group. Vitamin D supplementation may be beneficial in these patients with the immunomodulatory effect. Goetz et al. (71) also found vitamin $D$ treatment as successful at a rate of $70 \%$ in idiopathic urticaria and angioedema $(72,73)$.

Table 2. The role of vitamin $D$ in asthma and other allergic diseases

\begin{tabular}{|c|c|c|c|}
\hline Disease & Effect of vitamin D & Mechanism of action & References \\
\hline Asthma bronchitis & $\downarrow \uparrow$ & $\begin{array}{l}\text { Th2 } 2 \uparrow \downarrow \text {, Th1 } \uparrow \text {, Treg cell } \uparrow, \text { AMP } \uparrow, \beta \text {-defensin } \uparrow \text {, cathelicidin } \uparrow \text {, } \\
\text { CXCL10 in the respiratory epithelium and IFN- } \beta \downarrow\end{array}$ & $22-55$ \\
\hline Allergic rhinitis & $\downarrow \uparrow$ & Th2 $2 \downarrow$, Th1 $\uparrow$, Treg cell $\uparrow$ & $56-61$ \\
\hline Allergic conjunctivitis & $\downarrow \uparrow$ & 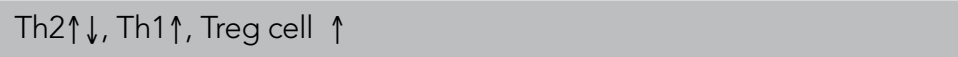 & $56-61$ \\
\hline $\begin{array}{l}\text { Atopic dermatitis } \\
\text { (Eczema) }\end{array}$ & $\downarrow \uparrow$ & $\begin{array}{l}\text { Stratum corneum } \uparrow \text {, filaggrin } \uparrow \text {, keratinocyte } \uparrow \text {, microorganism } \\
\text { colonization } \downarrow\end{array}$ & $62-66$ \\
\hline Urticaria /Angioedema & $\downarrow$ & Immunomodulation & $70-73$ \\
\hline Food allergy & $\downarrow$ & Intestinal permeability $\downarrow$, Th2 $\downarrow$, Treg cell $\uparrow$, tolerogenic dendritic cell $\uparrow$ & 69 \\
\hline
\end{tabular}




\section{CONCLUSION}

Although the lack of vitamin $D$ is suggested to be higher particularly in asthma and in other allergic diseases, its routine use in the prevention and treatment of allergic diseases is still not recommended (74). Serum 25(OH)D3 examination should be requested in dark-skinned patients with asthma (African-American and Hispanic-American), obese people, old people, those who work indoors and in an office, and those who live in places with less sunlight. In addition, there are recommendations to use vitamin D3 in moderate doses (1000-2000 IU/day) in asthma, especially in patients who use frequent systemic steroids and in patients with treatment-resistant asthma (75). It is also thought to be useful in patients with atopic dermatitis and chronic urticaria. The role of vitamin D in asthma and other allergic diseases is shown in Table 2.

Although we do not have an experience of using vitamin $D$ in allergic diseases, as we interpreted in light of the recent literature, we have concluded that the use of vitamin $D$ in selected patients with asthma may be beneficial. Therefore, there is a need for more studies for the determination of the proper dose, time, and person's genotype in order for vitamin $D$ to be used routinely in allergic diseases, and these important data need to be clarified in the future.

Peer-review: Externally peer-reviewed.

Author Contributions: Concept - Ö.Ö.; Design - Ö.Ö.; Supervision Ö.Ö.; Resources - Ç.K.; Materials - Ç.K.; Data Collection and/or Processing - Ç.K.; Analysis and/or Interpretation - Ö.Ö.; Literature Search - Ç.K.; Writing Manuscript - Ö.Ö.; Critical Review - Ö.Ö.; Other - Ç.K.;

Conflict of Interest: No conflict of interest was declared by the authors.

Financial Disclosure: The authors declared that this study has received no financial support.

\section{REFERENCES}

1. Global Strategy for Asthma Management and Prevention 2016. Available from: www.ginasthma.org. http://ginasthma.org/2016-ginareport-global-strategy-for-asthma-management-and-prevention/

2. Asher MI, Montefort S, Björkstén B, Lai CK, Strachan DP, Weiland SK, et al. Worldwide time trends in the prevalence of symptoms of asthma, allergic rhinoconjunctivitis, and eczema in childhood. Lancet 2006; 368: 733-43. [CrossRef]

3. Nurmatov U, Devereux G, Sheikh A. Nutrients and foods for the primary prevention of asthma and allergy: systematic review and metaanalysis. J Allergy Clin Immunol 2011; 127: 724-33. [CrossRef]

4. Moffatt MF, Gut IG, Demenais F, Strachan DP, Bouzigon E, Heath $S$, et al. A large-scale, consortium-based genomewide association study of asthma. N Engl J Med 2010; 363: 1211-21. [CrossRef]

5. Illi S, von Mutius E, Lau S, Bergmann R, Niggemann B, Sommerfeld $C$. Early childhood infectious diseases and the development of asthma up to school age: a birTh cohort study. BMJ 2001; 322: 390-5. [CrossRef]

6. Ball TM, Castro-Rodrigue JA, GriffiTh KA, Holberg CJ, Martine FD, Wright AL. Siblings, day-care attendance, and the risk of asthma and wheezing during childhood. N Engl J Med 2000; 343: 538-43. [CrossRef]

7. de Meer G, Janssen NA, Brunekreef B. Early childhood environment related to microbial exposure and the occurence of atopic disease at school age. Allergy 2005; 60: 619-25. [CrossRef]

8. Holick MF. Vitamin D: evolutionary, physiological and health perspectives. Curr Drug Targets 2011; 12: 4-18. [CrossRef]
9. Dursun A. D vitamininin kemik metabolizması dışındaki etkileri. Beslenmede Yenilikler I- II, Katkı Pediatri Dergisi 2007; 28: 225-34.

10. Zittermann $A$. Vitamin $D$ in preventive medicine: are we ignoring the evidence? Br J Nutr 2003; 89: 552-72. [CrossRef]

11. Deluca HF. Overview of general physiologic features and functions of vitamin D. Am J Clin Nutr 2004; 80: 1689-96. [CrossRef]

12. Holick MF. Vitamin D status: Measurement, interpretation and clinical application. Ann Epidemiol 2009; 19: 73-8. [CrossRef]

13. Holick MF. Vitamin D Deficiency. N Engl J Med 2007; 357: 266-81. [CrossRef]

14. Bringhurst FR, Demoy MB, Kronenberg HM. Vitamin D. Williams Textbook of Endokrinology (Larsen PR, Kronenberg HM, Melmed S, Polonsky KS ed). Tenth edition. Philadelphia, Saunders Elsevier 2003; 1317-23.

15. Mora JR, Iwata $M$, von Andrian UH. Vitamin effects on the immune system: vitamins $A$ and D take centre stage. Nat Rev Immunol 2008; 8: 685-98. [CrossRef]

16. White $\mathrm{JH}$. Vitamin $\mathrm{D}$ as an inducer of cathelicidin antimicrobial peptide expression: past, present and future. J Steroid Biochem Mol Biol 2010; 121: 234-8. [CrossRef]

17. Dimeloe S, Nanzer A, Ryanna K, Hawrylowicz C. Regulatory T cells, inflammation and the allergic response- The role of glucocorticoids and vitamin D. J Steroid Biochem Mol Biol 2010; 120: 86-95. [CrossRef]

18. Palomer X, Gonzalez-Clemente JM, Blanco-Vaca F. Role of vitamin $\mathrm{D}$ in The pathogenesis of type 2 diabetes mellitus. Diabetes Obes Metab 2008; 10: 185-97. [CrossRef]

19. Bar-Yoseph R, Bentur L, Goldbart A, Livnat G, Hakim F, Weisman Y, et al. A mutated vitamin $D$ receptor in hereditary vitamin $D$-resistant rickets prevents induction of bronchial hyperreactivity and inflammation. J Clin Endocrinol Metab. 2014; 99: E1610-6. [CrossRef]

20. Iordanidou M, Paraskakis E, Giannakopoulou E, Tavridou A, Gentile $G$, Borro $M$, et al. Vitamin $D$ receptor Apal a allele is associated with better childhood asthma control and improvement in ability for daily activities. OMICS 2014; 18: 673-81 [CrossRef]

21. Tizaoui K, Berraies A, Hamdi B, Kaabachi W, Hamzaoui K, Hamzaoui $A$, et al. Association of vitamin $D$ receptor gene polymorphisms with asthma risk: systematic review and updated meta-analysis of case control studies. Lung 2014; 192: 955-65. [CrossRef]

22. Wjst M. Introduction of oral vitamin $D$ supplementation and the rise of the allergy pandemic. Allergy Asthma Clin Immunol 2009; 5: 8. [CrossRef]

23. Wittke A, Weaver V, Mahon BD, August A, Cantorna MT, et al. Vitamin D Receptor-deficient mice fail to develop experimental allergic asthma. J Immunol 2004; 173: 3432-6. [CrossRef]

24. Junge KM, Bauer T, Geissler S, Hirche F, Thürmann L, Bauer M, et al. Increased Vitamin D levels at birth and in early infancy increase offspring allergy risk - Evidence for involvement of epigenetic mechanisms. J Allergy Clin Immunol 2016; 137: 610-3. [CrossRef]

25. Litonjua $A A$. Childhood asthma may be a consequence of vitamin $D$ deficiency. Curr Opin Allergy Clin Immunol 2009; 9: 202-7. [CrossRef]

26. Wjst M. The vitamin D slant on allergy. Pediatr Allergy Immunol 2006; 17: 477-83. [CrossRef]

27. Gale CR, Robinson SM, Harvey NC, Javaid MK, Jiang B, Martyn CN, et al. Maternal vitamin D status during pregnancy and child outcomes. Eur J Clin Nutr 2008; 62: 68-77. [CrossRef]

28. Camargo CA Jr, Ingham T, Wickens K, Thadhani R, Silvers KM, Epton MJ. Maternal intake of vitamin $D$ during pregnancy and risk of recurrent wheeze in children at $3 y$ of age. Am J Clin Nutr 2007; 85: 788-95. [CrossRef]

29. Devereux G, Litonjua AA, Turner SW. Maternal vitamin D intake during pregnancy and early childhood wheezing. Am J Clin Nutr 2007; 85: 853-9. [CrossRef]

30. Stelmach I, Majak P, Jerzynska J, Podlecka D, Stelmach W, Polańska K, et al. Cord serum 25-hydroxyvitamin D correlates with early childhood viral-induced wheezing. Respir Med 2015; 109: 38-43. [CrossRef] 
31. Camargo CA Jr, Ingham T, Wickens K, Thadhani R, Silvers KM, Epton $\mathrm{MJ}$, et al. Cord-blood 25-hydroxyvitamin D levels and risk of respiratory infection, wheezing, and asthma. Pediatrics 2011; 127: e180-7. [CrossRef]

32. Devereux G, Litonjua AA, Turner SW, Craig LC, McNeill G, Martindale $S$, et al. Maternal vitamin $D$ intake during pregnancy and early childhood wheezing. Am J Clin Nutr 2007; 85: 853-9. [CrossRef]

33. Chawes BL, Bønnelykke K, Stokholm J, Vissing NH, Bjarnadóttir E, Schoos AM, et al. Effect of vitamin D3 supplementation during pregnancy on risk of persistent wheeze in the offspring: A randomized clinical trial. JAMA 2016; 315: 353-61. [CrossRef]

34. von Mutius E, Martinez FD. Inconclusive results of randomized trials of prenatal vitamin $D$ for asthma prevention in offspring: curbing the enthusiasm. JAMA 2016; 315: 347-8. [CrossRef]

35. Litonjua AA, Carey VJ, Laranjo N, Harshfield BJ, McElrath TF, O'Connor $\mathrm{GT}$, et al. Effect of prenatal supplementation with vitamin $D$ on asthma or recurrent wheezing in offspring by age 3 years. The VDAART randomized clinical trial. JAMA 2016; 315: 362-70. [CrossRef]

36. Confino-Cohen R, Brufman I, Goldberg A, Feldman BS. Vitamin D asthma prevalence and asthma exacerbations: a large adult population-based study. Allergy 2014; 69: 1673-80. [CrossRef]

37. Rajabbik MH, Tamara L, Alkhaled L, Fares M, Fuleihan G, Mroueh S, et al. Association between low vitamin $D$ levels and the diagnosis of asthma in children: a systematic review of cohort studies. Allergy Asthma Clin Immunol 2014; 10: 31. [CrossRef]

38. Searing DA, Leung DYM. Vitamin D in atopic dermatitis, asthma and allergic diseases. Immunol Allergy Clin N Am 2010; 30: 397-409. [CrossRef]

39. Vassallo MF, Camargo CA Jr. Potential mechanisms for the hypothesized link between sunshine, vitamin $D$, and food allergy in children. J Allergy Clin Immunol 2010; 126: 217-22. [CrossRef]

40. Ginde AA, Mansbach JM, Camargo CA Jr. Association between Serum 25-Hydroxyvitamin $D$ level and upper respiratory tract infection in the third National Health and Nutrition Examination Survey. Arch Intern Med 2009; 169: 384-90. [CrossRef]

41. Cassim R, Russell MA, Lodge CJ, Lowe AJ, Koplin JJ, Dharmage SC. The role of circulating 25 hydroxyvitamin $D$ in asthma: a systematic review. Allergy 2015; 70: 339-54. [CrossRef]

42. Urashima M, Segawa T, Okazaki M, Kurihara M, Wada Y, Ida H. Randomized trial of vitamin $D$ supplementation to prevent seasonal influenza A in schoolchildren. Am J Clin Nutr 2010; 91: 1255-60. [CrossRef]

43. Brehm JM, Schuemann B, Fuhlbrigge AL, Hollis BW, Strunk RC, Zeiger RS, et al. Serum vitamin D levels and severe asthma exacerbations in the Childhood Asthma Management Program study. J Allergy Clin Immunol 2010; 126: 52-8. [CrossRef]

44. Pojsupap S, Iliriani K, Sampaio TZ, O'Hearn K, Kovesi T, Menon K, et al. Efficacy of high-dose vitamin $\mathrm{D}$ in pediatric asthma: a systematic review and meta-analysis. J Asthma 2015; 52: 382-90. [CrossRef]

45. Martineau AR, MacLaughlin BD, Hooper RL, Barnes NC, Jolliffe DA, Greiller $\mathrm{CL}$, et al. Double-blind randomised placebo-controlled trial of bolus-dose vitamin D3 supplementation in adults with asthma ( $\mathrm{Vi}$ DiAs). Thorax 2015; 70: 451-7. [CrossRef]

46. Black PN, Scragg R. Relationship between serum 25-hydroxyvitamin $d$ and pulmonary function in the third national health and nutrition examination survey. Chest 2005; 128: 3792-8. [CrossRef]

47. Gazibara T, den Dekker HT, de Jongste JC, McGrath JJ, Eyles DW, Burne $\mathrm{TH}$, et al. Associations of maternal and fetal 25-hydroxyvitamin D levels with childhood lung function and asthma: the Generation R Study. Clin Exp Allergy 2016; 46: 337-46. [CrossRef]

48. Bhalla AK, Amento EP, Clemens TL, Holick MF, Krane SM. Specific HighAffinity Receptors For 1,25-vitamin D3 in human peripheral blood mononuclear cells: presence in monocytes and induction in T lymphocytes following activation. J Clin Endocrinol Metab 1983; 57: 1308-10. [CrossRef]
49. Turkeli A, Ayaz O, Uncu A, Ozhan B, Bas VN, Tufan AK, et al. Effects of vitamin $D$ levels on asthma control and severity in pre-school children. Eur Rev Med Pharmacol Sci 2016; 20: 26-36.

50. de Groot JC, van Roon EN, Storm H, Veeger NJ, Zwinderman AH, Hiemstra PS, et al. Vitamin D reduces eosinophilic airway inflammation in nonatopic asthma. J Allergy Clin Immunol 2015; 135 670-5. [CrossRef]

51. Nanzer AM, Chambers ES, Ryanna K, Richards DF, Black C, Timms $\mathrm{PM}$, et al. Enhanced production of IL-17A in patients with severe asthma is inhibited by 1a,25-dihydroxyvitamin D3 in a glucocorticoid-independent fashion. J Allergy Clin Immunol 2013; 132: 297-304. [CrossRef]

52. Uysalol M, Mutlu LC, Saracoglu GV, Karasu E, Guzel S, Kayaoglu S, et al. Childhood asthma and vitamin D deficiency in Turkey: is there cause and effect relationship between them? Ital J Pediatr 2013; 39: 78. [CrossRef]

53. Heine G, Tabeling C, Hartmann B, González Calera CR, Kühl AA Lindner J, et al. 25-hydroxvitamin D3 promotes the long-term effect of specific immunotherapy in a murine allergy model. J Immunol 2014; 193: 1017-23. [CrossRef]

54. Bantz Selene K, Zhou Z, Zheng T. The role of vitamin D in pediatric asthma. Ann Pediatr Child Health 2015; 3: 1032.

55. Jerzynska J, Stelmach W, Rychlik B, Lechańska J, Podlecka D, Stelmach I, et al. The clinical effect of vitamin D supplementation combined with grass-specific sublingual immunotherapy in children with allergic rhinitis. Allergy Asthma Proc 2016; 37: 105-14. [CrossRef]

56. Yenigun A, Dadaci Z, Oncel M. Plasma vitamin D levels of patients with allergic rhino-conjunctivitis with positive skin prick test. Am J Rhinol Allergy 2015; 29: e46-9. [CrossRef]

57. Dadaci Z, Borazan M, Kiyici A, Oncel Acir N, et al. Plasma vitamin D and serum total immunoglobulin $E$ levels in patients with seasonal allergic conjunctivitis. Acta Opthalmol 2014; 92: e443-6 [CrossRef]

58. Jung JW, Kim JY, Cho SH, Choi BW, Min KU, Kang HR, et al. Allergic rhinitis and serum 25-hydroxyvitamin $D$ level in Korean adults. Ann Allergy Asthma Immvunol 2013; 111: 352-7. [CrossRef]

59. Dogru M, Suleyman A. Serum 25-hydroxyvitamin D3 levels in children with allergic or nonallergic rhinitis. Int J Pediatr Otorhinolaryngol 2016; 80: 39-42. [CrossRef]

60. Sagdic A, Sener O, Bulucu F, Karadurmus N, Özel HE, Yamanel L, et al. Oxidative stress status and plasma trace elements in patients with asthma or allergic rhinitis. Allergol Immunopathol (Madr) 2011; 39: 200-5. [CrossRef]

61. Goksugur SB, Erdurmus M, Bekdas M, Erkocoglu M, Agca S, Tosun $M$, et al. Tear and serum vitamin $D$ levels in children with allergic rhinoconjunctivitis. Allergol Immunopathol (Madr) 2015; 43: 533-7. [CrossRef]

62. Akan A, Azkur D, Ginis T, Toyran M, Kaya A, Vezir E, et al. Vitamin D level in children is correlated with severity of atopic dermatitis but only in patients with allergic sensitizations. Pediatr Dermatol 2013; 30: 359-63. [CrossRef]

63. Camargo CA Jr, Ganmaa D, Sidbury R, Erdenedelger Kh, Radnaakhand N, Khandsuren B. Randomized trial of vitamin D supplementation for winter-related atopic dermatitis in children. J Allergy Clin Immunol 2014; 134: 831-5. [CrossRef]

64. Benetti C, Piacentini GL, Capristo C, Boner AL, Peroni DG. Microorganism-induced exacerbations in atopic dermatitis: a possible preventive role for vitamin D? Allergy Asthma Proc 2015; 36: 19-25. [CrossRef]

65. Samochocki Z, Bogaczewicz J, Jeziorkowska R, Sysa-Jędrzejowska A, Glińska $O$, Karczmarewicz $E$, et al. Vitamin D effects in atopic dermatitis J Amer Academy Dermatol 2013; 69: 238-44. [CrossRef]

66. Bath-Hextall FJ, Jenkinson C, Humphreys R, Williams HC. Dietary supplements for established atopic eczema. Cochrane Database Syst Rev 2012; 2: CD005205. [CrossRef] 
67. Mullins RJ, Clark S, Camargo CA Jr. Vitamin D-Anaphylaxis Hypothesis. Ann Allergy Asthma Immunol 2009; 103: 488-95. [CrossRef]

68. Camargo CA Jr, Clark S, Kaplan MS, Lieberman P, Wood RA. Regional differences in EpiPen prescriptions in the United States: the potential role of vitamin D. J Allergy Clin Immunol 2007; 120: 131-6. [CrossRef]

69. Vasallo MF, Camargo CA Jr. Potential mechanisms for the hypothesized link betweem sunshine, vitamin $D$, and food allergy. J Allergy Clin Immunol 2010; 126: 217-22. [CrossRef]

70. Thorp WA, Goldner W, Meza J, Poole JA. Reduced vitamin D levels in adult subjects with chronic urticaria. J Allergy Clin Immunol 2010; 126: 413. [CrossRef]

71. Goetz DW. Vitamin D treatment of idiopathic itch, rash, and urticaria/angioedema. Allergy Asthma Proc 2010; 31: 158-60. [CrossRef]
72. Boonpiyathad T, Pradubpongsa P, Sangasapaviriya A. Vitamin d supplements improve urticaria symptoms and quality of life in chronic spontaneous urticaria patients: a prospective case-control study. Dermatoendocrinol 2014; 6: e29727.

73. Rasool R, Masoodi KZ, Shera IA, Yosuf Q, Bhat IA, Qasim I, et al. Chronic urticaria merits serum vitamin $D$ evaluation and supplementation; a randomized case control study. World Allergy Organ J 2015; 8: 15. [CrossRef]

74. Della GA, Landi M, Bellini F, Bosoni M, Ferrante G, Onorari M, et al. Vitamin $D$, allergies and asthma: focus on pediatric patients. World Allergy Organ J 2014; 7: 27.

75. Benetti C, Comberiati P, Capristo C, Boner AL, Peroni DG. Therapeutic effects of vitamin $D$ in asthma and allergy. Mini Rev Med Chem 2015; 15: 935-43. [CrossRef] 